\title{
An Evaluation of the Management of Office Buildings in the Public Sector of Botswana
}

\author{
Johnson Kampamba \\ University of Botswana, Faculty of Engineering and Technology, \\ Department of Civil Engineering, Land Management and Geomatics Section \\ Email: Johnson.kampamba@mopipi.ub.bw
}

\author{
Doi:10.5901/mjss.2015.v6n4s3p350
}

\section{Abstract}

\begin{abstract}
Purpose - The purpose of this paper was to evaluate the management of office buildings in the public sector of Botswana. Research design/methodology/approach - Both qualitative and quantitative research methods (interviews and questionnaire) were used to obtain data in order to meet the objective of the study. A survey involving a self-administered questionnaire to property managers/Estate officers in the department of Lands was used. Significance - The study is relevant in the sense that it will establish how much information is readily available on this particular topic. Findings - The study revealed that there was generally a lack of information on the offices that are managed by the Department of Lands due to a number of factors. The study also found that the leasing/rental expenditure has reduced to P28 million per annum as compared to the previous results which showed annual expenditure of P96 Million in 2005. This is as a result of the two new buildings that the government has constructed (Kampamba \& Cloete, 2009; Kampamba \& Cloete, 2010). Originality/value - From the key findings, recommendations are made in this paper to improve the management of office buildings.
\end{abstract}

Keywords: Office buildings, Public sector, Management, Botswana

\section{Introduction}

The paper is based partly on the work carried out on a mini research project done in Bachelor of Land Management Programme in 2013. The main issue of concern is that most governments have buildings which are not accounted/or not having an asset database regarding their use, space utilised and the inherent value of such assets. The Botswana government is not an exception to this problem, despite having invested so much money in the development of office buildings in the last ten years. At the time the author was the course Lecturer in Property Management a course that is taken by third year students of Land Management Programme.

The purpose of the research was to establish the extent to which property management, space utilisation and planning and asset management is practised in the public sector of Botswana.

\section{Background of Botswana}

This is a middle income country which has transformed from a least developed nation and maintained one of the world's highest economic growth rates since gaining independence in 1966 through the careful use of foreign direct investment (UNCTAD, 2003). Foreign direct investment (FDI) to Botswana accounted for 17.8 percent of the gross fixed capital formation in contrast to an average of 12.8 percent for all developing countries (World Investment Report, 2010). The main contributor to economic growth and development is diamonds which accounts for 80 percent of foreign exchange earnings. Other major contributors to economic growth are cattle farming, tourism and financial services. Matambo (2010) in his budget speech highlighted that the gross domestic product (GDP) for 2009 was at P86.2 billion measured at current prices. The average GDP economic growth for the first three years of NDP 10 was 3.6 percent (Botswana Review, 2014).

\section{Literature Review}

Brown, Lapides, \& Rondeau (1995) states that property management is frequently described as a profitable operation and management of owned, leased or subleased real property including land, buildings, assets, equipment and legal commitments for an owner or developer, while Jones \& White (2008) defines property management as an activity that ensures that land and buildings are dealt with so that they operate efficiently and effectively. On the other hand, Scarret 
(1983) defines property management as the implementation of policy decisions and the accomplishment of the property owner's objectives. Property managers employed in the public sector will manage property for owner occupation or consumption with an objective of maintaining the suitability of the property for the required use (Cloete, 2002). The public sector is part of the macro economy which comprises state owned institutions and assets (Sinclair, Wilkes and Krebs, 1999, cited by Deloitte 2012).

Jones and White (2008) states that property measures are often broken down into a range of more focused component parts normally related to efficiency, effectiveness and economy. These are cost and control; space utilisation, service levels and customer satisfaction, risk management including health and safety; in-house services management and outsourced supplier management. The need for effective property management may reduce operating costs, dispose of excess properties or hold on troubled properties by improving their operating income (Isa, 2013). This will eventually lead to service improvement on the end user thus enhancing the quality of service provided. However, Deloitte (2012) highlighted that property management is often marginalised from the high level decision making process, amongst them are government executives who deal with policy making and meeting mission objectives. He further stressed that the prevailing culture around property management must be dismantled in order to achieve any measurable improvements.

The need for property management in any organisation including the public sector is stressed by Isa (2013) who asserts that property assets are very important to all organisations as it contributes to their success. He further hinted that large amounts of money are devoted to such assets, hence the need to manage them efficiently and effectively thus (my emphasis) adding value to the public sector real estate assets.

On the other hand, Joroff (1992) reiterates that there is no single best model that could suggest the type of property management activities that can be organised and related to other management functions within large organisations particularly the public sector. The choice of activities constituting property management will mainly depend on the objectives of the property management itself.

\section{Methodology}

Quantitative as well as qualitative research methods (records searches and questionnaires) were used to obtain data in order to achieve the objective of the study. A survey instrument was developed and administered to Property Managers/Estates Officers to establish the extent of property management practice within the public sector of Botswana. The reason for use of the questionnaire was to try and find answers to the research questions raised. Included in the questionnaire were sections on extent of practice on property management, space planning and utilisation, and asset management of government office buildings. Some questions were open ended and others were in a form of a likert scale. The study was confined to Gaborone the capital city of Botswana due to the fact that it was the most convenient location for the researcher. The respondents were officers employed in the Department of Lands under the Ministry of Lands and Housing who by default are the property managers for government owned real property. The selection of a sample was done using a non-probability purposive sampling and this is the most economical convenient method of sampling. District Estate Officers, Land boards and Councils Estate Officers were not part of the respondents that were administered with the questionnaire. Properties that falls under Land Boards and Councils does not form part of this research discussion.

The numeric data was analysed statistically using Microsoft Excel and content analysis was used for semi structured interviews.

\section{Findings}

In order to achieve the purpose of the research study, this was to establish the extent of the practice of property management; space planning and utilisation and asset management within the public sector of Botswana. The following research objectives were developed to help address the research problem. These were as follows:

a) To establish the extent of the practice of property management.

b) To find out how space planning and management/utilisation is carried out/monitored.

c) To establish the existence of the asset register and how asset management is undertaken.

A questionnaire was developed containing the following questions using the likert scale (1 being Strongly Disagree, 2 Disagree, 3 I don't know or not sure, 4 Agree, 5 strongly Agree). These are:

1. The respondents were asked to state as to what extent they agree that the Department of Lands was responsible for the functions listed in the chart below ( 1 being strongly disagree and 5 strongly agree). 


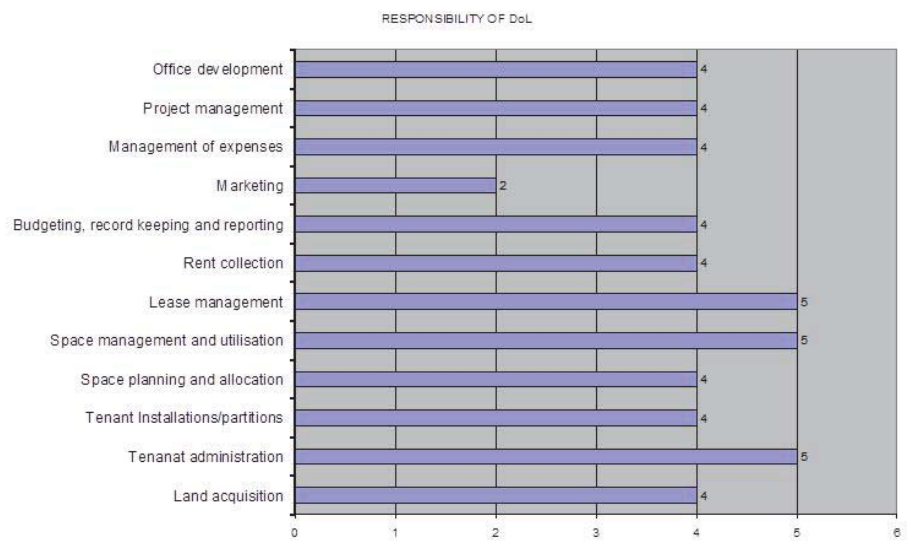

Figure 1: Responsibility of DoL

All the respondents scored either 4 or 5 on the responsibilities of the Department of Lands, except for marketing where the score was 2 indicating that it was not the responsibility of the department to market the office space to prospective users. The reason being that the properties that are managed are not income generating but occupied as a support service to ensure that the government delivers on its mandate of service provision. Apart from the score for marketing, it is indicative that the officers are conversant with the mandate of the department which is delivering space to government ministries and departments in a most efficient and effective way.

2. The respondents were asked to indicate to what extent they agreed with the statement that "The property manager's function can be divided into four levels of management". The respondents were asked to what extent they agreed with the above statement and it was clear from the scores that they all agreed that the function of a property manager can be divided into four function levels of management as outlined in figure 2 below. This suggests that the respondents are aware that management of property by a property manager can be done even at a higher level such as strategic or top management level due to the importance that is attributed to property by the top management within the public sector. Real property is considered as a key supporting service in as far as non-core business is concerned within the organisation. Regardless of whatever functional level of management they are executing their daily duties in confined and defined space known as office accommodation. The important aspect is that no government service can be delivered without having an office space where that service can be provided to the public.

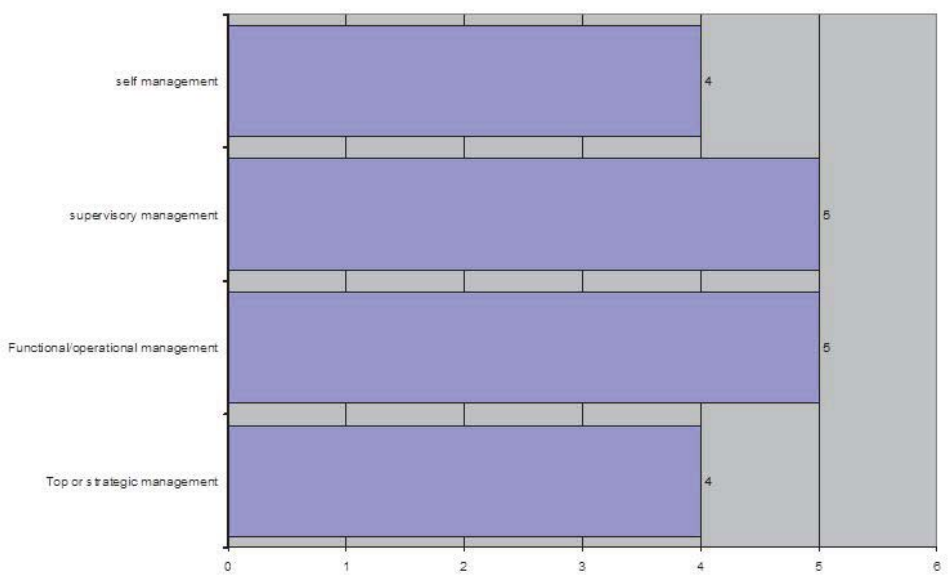

Figure 2: Levels of management 
3. Respondents were requested to indicate the level of agreement on the statement that "the reason for property management is to maintain the value of the property and hopefully increase the value as long as it was in their power to do so".

From the responses of the respondents shown in table 1 below, it is clear that 70 per cent agreed with the statement that the reason for property management was to maintain the value of the property and hopefully increase the value as long as it is in the power of the property manager to do so. 15 per cent were not in support of the statement and the remaining 15 percent were not sure if property management would maintain and increase the value of the property. The result implies that respondents are very much aware that managing property effectively will lead to an increase in the value of the property. The majority of the respondents appreciate that and are aware of the fact if property is not managed well, occupiers/users' productivity might be affected.

Table 1: Reasons for property management

\begin{tabular}{ccc} 
Type of response & Percent (\%) & Count \\
\hline Agree & $30 \%$ & 6 \\
Disagree & $15 \%$ & 3 \\
Not sure & $15 \%$ & 3 \\
Strongly agree & $40 \%$ & 8 \\
\hline Grand Total & $100.00 \%$ & $\mathbf{2 0}$
\end{tabular}

4. Respondents were requested to indicate the level of agreement on the statement that "The purpose of managing public sector office property is to maintain suitability of the property for the required use". From the responses of the respondents shown in table 2 below, it was clear that they were all in agreement with the statement that the purpose of managing public sector office property was to maintain the suitability of the property for specific required use. This implies that the property managers are fully knowledgeable of the fact that if the property is not managed professionally, it might not facilitate the production of a service by not being suitable and adaptable to the users of the facility.

Table 2: Purpose of managing property

\begin{tabular}{ccc} 
Type of Response & Percent (\%) & Frequency \\
\hline Agree & $45 \%$ & 9 \\
Strongly agree & $55 \%$ & 11 \\
\hline Grand Total & $100.00 \%$ & 20
\end{tabular}

5. "The record of properties occupied by ministries and departments is readily available". Respondents were asked to state whether they agree with the statement that the records for government office buildings are readily available. From the results in figure 3,80 percent disagreed implying that the property records are not readily available, while 15 percent agreed to some extent that records were available for properties that are occupied by government ministries and departments. The implication of this is that estate managers spend most of their effort managing and documenting privately owned property which is leased to government thus neglecting keeping track of their portfolio owned by government. This signifies the need to have property records readily available for planning and space management purposes.

Availa bility of rec ords for govemment owned property

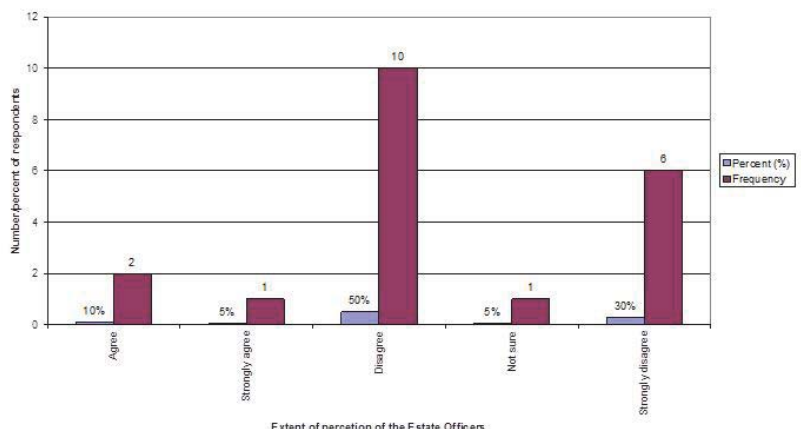

Figure 3: Availability of Property records. 
6. The respondents were asked to what extent does they agree or disagree with the statement that "The asset register is available for use in the department". The results of the survey showed that 100 percent were of the view that there was no asset register for government owned property. What this implies is that the management might not even know the worth of the government property portfolio. It is important that every asset owned is well documented so that accountability is easy when the need arise. As it is now, it is very difficult to account for the property that is owned by the government in terms whether it is underutilised or fully occupied. The asset register will help solve such issues once developed because one will be able to know when it was built, history of maintenance/occupancy and how much space is still available within that property for efficient utilisation.

Table 3: Availability of an Asset Register

\begin{tabular}{ccc} 
Type of response & Percent (\%) & Frequency \\
\hline Agree & $0 \%$ & 0 \\
Strongly agree & $0 \%$ & 0 \\
Disagree & $70 \%$ & 14 \\
Not sure & $0 \%$ & 0 \\
Strongly disagree & $30 \%$ & 6 \\
\hline Grand Total & $\mathbf{1 0 0 . 0 0 \%}$ & $\mathbf{2 0}$
\end{tabular}

7. The respondents were asked to indicate their opinion with regard to the statement that "Information about the tenancy or occupancy rates is readily available for government office building property". According to the responses obtained as illustrated in table 4 below, 75 percent of the respondents did not attest to the statement that information about the occupants was documented and readily available. 15 percent stated that the information that was available is only for newly completed buildings and as for the old ones which were built long time ago, there were no records of occupancy in the department. What this means is that a physical survey has to be undertaken in order to establish the current occupants and how much space they are occupying has to be documented.

Table 4: Reasons for property management

\begin{tabular}{ccc} 
Types of response & Percent (\%) & Frequency \\
\hline Agree & $10 \%$ & 2 \\
Strongly agree & $5 \%$ & 1 \\
Disagree & 50 & 10 \\
Not sure & 10 & 2 \\
Strongly disagree & 25 & 5 \\
\hline Grand Total & $100.00 \%$ & $\mathbf{2 0}$
\end{tabular}

8. Respondents were asked to indicate whether to agree or disagree with the statement that "The open market value of each property is captured in the asset register". From the responses in table 5 below, it is clear that 100 percent confirmed that there was no market value captured in the asset register because even the latter did not exist within the department that is responsible for managing government property. The implication is that government fixed assets are not accounted for in terms of how much they are worth. This could mean that governments are not under pressure to produce balance sheets for their assets and liabilities that is why this is not a priority as opposed to parastatal organisations where every two years they need to revalue their property portfolio to establish how it is worth.

Table 5: Market value captured in the asset register

\begin{tabular}{ccc} 
Types of response & Percent (\%) & Frequency \\
\hline Agree & $0 \%$ & 0 \\
Disagree & $60 \%$ & 12 \\
Not sure & $0 \%$ & 0 \\
Strongly agree & $0 \%$ & 0 \\
Strongly disagree & $40 \%$ & 8 \\
\hline Grand Total & $100.00 \%$ & 20 \\
& & \\
& 354 &
\end{tabular}


9. The respondents were asked to indicate the extent of agreement with the statement that"The guidelines regarding space allocation are available for use in the department". It was evident that the allocation of space guidelines were used especially for property that is leased from the private owners for use by the government for it its business. 100 percent agreed that space allocation guidelines were used both for space planning/management and allocation of budget resources purposes. These guidelines are based on the post of an officer being entitled to a certain amount of space. A request for allocation of government office space is based on the post and then the area/size of office space is determined. Space users are advised to submit a list of employees together with their grades so that space can be determined for budgeting purposes, the amount of space in square metres is determined and multiplied by a rate per metre squared currently being obtained in the market.

Table 6: Availability of guidelines for space allocation and planning

\begin{tabular}{ccc}
\hline Types of Response & Percent (\%) & Count \\
\hline Agree & $45 \%$ & 9 \\
Disagree & $0 \%$ & 0 \\
Not sure & $0 \%$ & 0 \\
Strongly agree & $55 \%$ & 11 \\
\hline Grand Total & $100.00 \%$ & 20
\end{tabular}

10. The respondents were asked to indicate the extent of agreement with the statement that "Space needs and assessment are done based on the space allocation guidelines". From the analysis of the responses from the questionnaire, 100 percent in totality agreed that for the purpose of allocating resources and establishing the space needs, the space allocation guidelines are used.

From the above discussion of results, it is clear that the management of office buildings in the public sector of Botswana has been met with challenges which one needs to unlock in order to experience the full potential benefits of professional property management. Taking comparison between Botswana case and the study done in Canada, one would identify a number of differences in the management of public sector office buildings. The table below tries to illustrate differences and similarities on management between the two countries.

Table 7: A comparative analysis of government property in Botswana and Canada.

\begin{tabular}{|c|l|l|l|}
\hline Item No. & Description of items of concern & Botswana & Canada \\
\hline 1 & Properties managed & Government offices & State owned property including office buildings. \\
\hline 2 & Responsible Department & $\begin{array}{l}\text { Department of Lands (Ministry } \\
\text { of Lands and Housing) }\end{array}$ & $\begin{array}{l}\text { Real Estate Branch (Public Works and Government } \\
\text { Services Canada) }\end{array}$ \\
\hline 3 & Worth of properties being managed & No information & CA\$6.5 billion \\
\hline 4 & Size of office space managed & No information & 7.14 million square metres \\
\hline 5 & Size of office space owned by government & No Information & 3.11 Million square metres \\
\hline 6 & Size of space leased & No Information & 3.50 Million square metres \\
\hline 7 & Size of space on lease-purchase & No Information & 0.53 Million square metres \\
\hline 8 & Number of offices leased & 350 buildings & 1500 buildings \\
\hline 9 & Number of locations where buildings are situated & No Information & 1855 locations \\
\hline 10 & Cost of lease per annum & P28 Million & CA\$1.11 billion \\
\hline 11 & Insurance of office buildings & Not Insured & Not Insured \\
\hline
\end{tabular}

Source: Canada information from Deloitte, 2012.

From the above analysis, it is evident that Botswana Government has a deficit of information pertaining to the property they are managing. It is vital that there be an asset register for all the properties owned by the government. This will make it easy for them to know where a particular property is situated and how its condition is at a particular time. There will be need for the register to be updated continually on issues relating to the conditions of the various properties. It is mentioned that government pay approximately P28 million annually on leased properties. Despite the fact that they part every year with this huge amount of money as rental, there seem to be no justification from their side as to whether the amount paid is in-line with the demands of the open office market. It is clear that the information that is available is for property leased from the private sector property market. 


\section{Conclusions}

An evaluation of the management of public sector office buildings in Botswana revealed the following:

1. Department of Lands is responsible for the management of lease nationwide with Francistown manning 200 leases for Sowa, Francistown, Selebi-Phikwe and Kasane while Gaborone Office responsible for those in Jwaneng, Ghanzi, Lobatse and Gaborone

2. In terms of maintenance of government office buildings, it is the responsibility of Department of Buildings and Engineering Services.

3. It is important to appreciate that property is a valuable resource and public sector organisations have started to take steps to divorce the primitive styles of property management and come up with improved management practices.

4. From the interview it was evident that there were inaccurate and unreliable records and this impact negatively on the quality and promptness of decision making process. There is no inventory and database of government owned properties and yet it owns so much property.

5. At the time the interview/survey was carried out, it was established that government had rented about 350 properties from the office market at a cost of P28 Million, and that there was no manual used in the operation/management of government office buildings.

6. The other challenge was that there were no resources to manage the geographically spread property portfolio. After decentralisation of the portfolio, user departments are not following the procedures and guidelines for management of government property.

7. It was also established that the Ministry of Lands and Housing as the Government Estates Manager is then responsible for coordinating acquisition of office space for government use through the Department of Lands whose duties comprise lease management, rental negotiation, lease renewal, tenancy scheduling, space auditing and facilities management. The acquisition of office buildings is either through construction of new buildings or rental and purchase of existing properties on the market.

\section{Recommendations}

A closer look on the issues raised in the conclusion, one would come up with the following recommendations which are aimed at addressing the challenges and issues concomitant with this study. These are:

1. Improve on the information management systems to enable the capture of data about the existing government owned buildings. It is important to realise that for an organisation to work efficiently it will require information in order to make informed decisions. Issues such as creation of an asset register should be considered for properties that are owned by the government.

2. Consider investing in resources such as human resources in order to improve on the efficiency at which the property owned by government is managed and that prioritise the management of assets by empowering the asset managers so that recent information is provided when managing the built up assets.

3. Space management should translate the organisational objectives into spatial relationships of its functions together with the needs of the people who perform the functions.

\section{References}

Botswana Review. (2014). Botswana Review of Commerce and Industry. Gaborone: B \& T Directories (Pty) Ltd. Brown, R. K., Lapides, P. D., \& Rondeau, E. P. (1995). Facility Management. New York: John Wiley \& Sons Inc.

Cloete, C. E. (Ed.). (2001). Principles of Property Management (2 ed.). Sandton: South African Nation Property Education Trust. Deloitte. (n.d.). Deloitte . Retrieved March 13, 2013, from Deloitte: www.deloitte.com

Isa, Z. M. (2013, March 19). Retrieved March 19, 2013, from www.fig.net

Jones, K., \& White, D. A. (2008). RICS Public Sector Asset Management Guidelines. London: Royal Institution of Chartered Surveyors.

Joroff, L. M. (1992). Corporate Real Estate 2000: Management strategies for the next decade. Norcross: Industrial Development Research Foundation.

Kampamba, J., \& Cloete, C. E. (2009). The Office Market in Botswana. 4th Built Environment Conference (pp. 169-180). Livingstone: ASOCSA RFM Design.

Kampamba, J., \& Cloete, C. E. (2010). The office market in Botswana. The SAPOA Real Estate Research Yearbook, 178-185.

Matambo, K. (2010). "Transforming our economy after the crisis: 2010 and beyond" 2010 Budget Speech. Gaborone: Government Printers.

Scarret, D. (1983). Property Management. London: E \& F.N. Spon.

UNCTAD. (2003). Investment Policy Review - Botswana. New York: United Nations.

World Investment Report. (2010). Retrieved June 12, 2010, from www.unctad.org/section/dite_dir/docs/wir06_fs_bw_en.pdf 